\title{
Thermal and Electric Storage Optimization for Solar-Assisted Heat Pump Systems in Residential Buildings
}

\author{
Maria Pinamonti ${ }^{1}$, Paolo Baggio ${ }^{2}$ \\ ${ }^{1}$ Free University of Bozen-Bolzano, Bolzano, Italy \\ ${ }^{2}$ University of Trento, Trento, Italy
}

\begin{abstract}
The paper presents a parametric study that investigates the role of energy storage technologies in solar-assisted heat pump (SAHP) systems. The aim is to increase the selfconsumption of renewable energy of the systems using thermal and electric storages without oversizing the system, while minimizing the installation cost. The analysis is carried out for both heating and cooling seasons. Several configurations of solar-assisted heat pump systems are assessed by means of energy consumption and cost, for a reference period of 20 years. A standard air-source heat pump is defined as reference system, to compare the results obtained for the SAHP solutions, in terms of reduction of the energy consumption and money saving.
\end{abstract}

\section{Introduction}

The building sector covers an important part of the energy consumption in Europe. In 2015, Eurostat reported a final energy consumption rate of 1084 Mtoe for the European Union (EU) countries. About $40 \%$ of the total consumption amount is related to the building use. In the same year, the European primary energy production of renewable energy reached 205 Mtoe, which is roughly $19 \%$ of the final consumption. Considering the data provided by Eurostat in 2015, the renewable energy production is supplied mainly by hydropower $(14 \%)$, wind power $(13 \%)$, solar power $(6 \%)$, and geothermal energy systems (3\%).

Several directives were implemented by EU to increase the use of renewable energy sources and reduce the final energy consumption (Antoniadis and Martinopoulos 2017): the Directive 2009/28/EC fixed a 20\% target for the overall renewable energy share by 2020 (European Parliament 2009); the Directive 2010/31/EC defined the minimum performance factors for existing and new buildings, and introduced the Net Zero Energy Building (NZEB) concept (European Parliament 2010). The NZEB is characterized by a very low energy demand and a large share of renewable energy produced on-site or nearby. Among other solutions, heat pump systems are considered a very promising technology to reach these energy efficiency targets.

The use of heat pumps for cooling and heating in buildings allows to design electricity-based systems that have the potential to reduce the use of fossil fuels in the sector (Januševičius and Biekšienè 2013). For example, the combination of heat pump systems with rooftop solar installations (PV or thermal) leads to a large production and self-consumption of renewable energy on-site (Tzivanidis et al. 2016; Bellos and Tzivanidis 2017; Lerch, Heinz, and Heimrath 2014; Buker and Riffat 2016). Several scientific and technological issues have been identified concerning the design of solar-assisted heat pump systems and, for this reason, control strategies and an optimal design are required (Hardorn 2015). Many studies about SAHP systems are related to the project IEA SHC Task44/HPP Annex 38 (T44A38) "Solar and Heat Pump Systems" (M. Haller et al. 2013), launched in 2010 within the Solar Heating and Cooling Program and the Heat Pump Program by the IEA (International Energy Agency). The project lasted 4 years and more than 50 participants from 13 countries have collaborated to achieve common goals about research, development and demonstrations about solar and heat pump systems. Different solutions for SAHP system configurations were proposed and tested. Considering these systems, two of the main issues are the intermittency of the renewable energy source and the time gap occurring between the solar energy availability and the energy demand of the building. To bridge this gap, the demand side management and the use of energy storage are the most widely accepted solutions to ensure the optimal operation of the systems.

Energy storage technologies integrated with solarassisted heat pump systems are a profitable solution to increase the self-consumption of solar energy in the building (Battaglia et al. 2017; Fischer et al. 2017; Moser et al. 2017; Bee, Prada, and Baggio 2016). The solar energy is accumulated in the storage during the peak production hours until the building requires it, instead of being wasted or sent to the grid (Facci et al.). Electric and thermal storage technologies have been studied for different application in SAHP systems. Thermal storages can use latent or sensible heat to collect the energy. By increasing the temperature level of the storage, the amount of energy that can be stored increases, but at the same time also the thermal losses increase. In addition, if the thermal storage is used to store the energy produced by the heat pump during the PV operation hours, the increase of the storage temperature leads to a decrease in the heat pump performance. Considering water as the most widely used storage medium, the heat storage capacity is about $70 \mathrm{Wh} / \mathrm{m}^{3}$, using temperatures between 20 and $80^{\circ} \mathrm{C}$ (Hardorn 2015). Higher capacities could be 
reached with higher temperatures of the storage, but the temperature level for the storage integration in a solarassisted heat pump system is limited by the maximum condenser temperature of the heat pump. The energy capacity of a water thermal storage is very low if compared with the best available electric storage technologies. For instance, the energy capacity for a lithium-ion battery goes from 150 to $200 \mathrm{Wh} / \mathrm{kg}$ (Ibrahim, Ilinca, and Perron 2008). On the other hand, other important parameters should be considered when comparing electric and thermal storages, such as costs and the lifespan of the technologies. For a small-scale $\mathrm{LiFePo} 4$ battery suitable for residential use, the average price of around $1000 € / \mathrm{kWh}$ was reported in 2017 (Moser et al. 2017), with a predictable calendar life of 15 years (Moser et al. 2017) and a progressive decrease of the efficiency during the period.

The majority of the studies about solar-assisted heat pump systems consider only heating and domestic hot water production. Only few studies analyse cooling application (Henning 2007). The applications of cooling technologies with thermal solar collectors has a small diffusion, due to high costs and technical obstacles to reach adequate performance level (Al-alili, Hwang, and Radermacher 2013).

In this paper, the analysis of SAHP systems is carried out for three reference buildings having different energy demand levels, considers both heating and cooling application. The impact of the integration of thermal and electric storage on the overall system consumption is assessed investigating different system configurations and control strategies. The results are expressed as primary energy consumption and installation costs, to identify the optimal solutions over a reference period of 20 years.

\section{Methods}

\section{Case study}

For the system simulations a reference building is considered (Figure 1), based on the boundary conditions of IEA SHC Task44 (M. Haller et al. 2013). The reference building proposed in this study is a two-storey building with $140 \mathrm{~m}^{2}$ heated floor area $(\mathrm{S} / \mathrm{V}=0.59)$. The building is divided in four thermal zones: two thermal zones are defined for each floor of the building, one in the north part and one in the south part of the building.
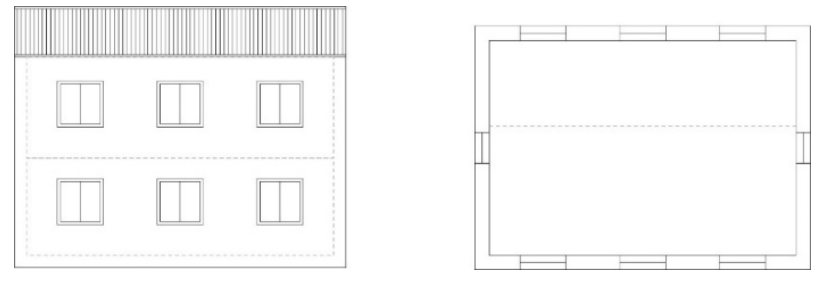

Figure 1: reference building for the case study

The insulation thickness of the building envelope varies, defining three different building-load scenarios: a high insulated, a medium insulated, and a low insulated building are defined to represent namely an unrefurbished, a refurbished and a new building. The buildings are characterised as shown in Table 1.

Table 1: Average thermal transmittance levels of the building envelope

\begin{tabular}{|c|c|c|c|}
\hline & $\begin{array}{c}\text { High } \\
\text { insulation }\end{array}$ & $\begin{array}{c}\text { Medium } \\
\text { insulation }\end{array}$ & $\begin{array}{c}\text { Low } \\
\text { insulation }\end{array}$ \\
\hline Wall & $0.18 \mathrm{~W} / \mathrm{m}^{2} \mathrm{~K}$ & $0.25 \mathrm{~W} / \mathrm{m}^{2} \mathrm{~K}$ & $0.66 \mathrm{~W} / \mathrm{m}^{2} \mathrm{~K}$ \\
\hline Ground floor & $0.18 \mathrm{~W} / \mathrm{m}^{2} \mathrm{~K}$ & $0.26 \mathrm{~W} / \mathrm{m}^{2} \mathrm{~K}$ & $0.54 \mathrm{~W} / \mathrm{m}^{2} \mathrm{~K}$ \\
\hline Roof & $0.17 \mathrm{~W} / \mathrm{m}^{2} \mathrm{~K}$ & $0.24 \mathrm{~W} / \mathrm{m}^{2} \mathrm{~K}$ & $0.60 \mathrm{~W} / \mathrm{m}^{2} \mathrm{~K}$ \\
\hline Window & $0.86 \mathrm{~W} / \mathrm{m}^{2} \mathrm{~K}$ & $1.27 \mathrm{~W} / \mathrm{m}^{2} \mathrm{~K}$ & $2.68 \mathrm{~W} / \mathrm{m}^{2} \mathrm{~K}$ \\
\hline Ceiling & $0.20 \mathrm{~W} / \mathrm{m}^{2} \mathrm{~K}$ & $0.38 \mathrm{~W} / \mathrm{m}^{2} \mathrm{~K}$ & $0.41 \mathrm{~W} / \mathrm{m}^{2} \mathrm{~K}$ \\
\hline
\end{tabular}

The annual energy demand of the buildings is calculated for the climate of Bozen, in northern Italy. The heating and cooling demand are obtained using the TRNSYS simulation software and considering the climate data of the test reference year. The time-step used in the simulations is 1 hour. The building is modelled using the multi-zone building subroutine type 56 in TRNSYS. The domestic hot water (DHW) demand is estimated of around 1861 per day based on the Italian standards, considering the hourly demand profile defined by the European Standard (European Committee for Standardization-CEN 2016). The DHW tank is defined using type 4 , with a capacity of 1501 and a loss coefficient of $0.83 \mathrm{~W} / \mathrm{m}^{2} \mathrm{~K}$. The air change rate is set to $0.5 \mathrm{vol} / \mathrm{h}$ during the heating season and $1.5 \mathrm{vol} / \mathrm{h}$ during the cooling season. For the high insulation case, a heat recovery ventilation system is considered. The total energy demand for the three cases are $40.2 \mathrm{kWh} / \mathrm{m}^{2}, 79.2 \mathrm{kWh} / \mathrm{m}^{2}$ and $143.5 \mathrm{kWh} / \mathrm{m}^{2}$, as shown in Table 2 .

Table 2: Building energy loads for each reference scenarios

\begin{tabular}{|c|c|c|c|}
\hline & $\begin{array}{c}\text { High } \\
\text { insulation }\end{array}$ & $\begin{array}{c}\text { Medium } \\
\text { insulation }\end{array}$ & $\begin{array}{c}\text { Low } \\
\text { insulation }\end{array}$ \\
\hline Heating & $18.8 \mathrm{kWh} / \mathrm{m}^{2}$ & $57.6 \mathrm{kWh} / \mathrm{m}^{2}$ & $122 \mathrm{kWh} / \mathrm{m}^{2}$ \\
\hline Cooling & $4.5 \mathrm{kWh} / \mathrm{m}^{2}$ & $4.6 \mathrm{kWh} / \mathrm{m}^{2}$ & $4.6 \mathrm{kWh} / \mathrm{m}^{2}$ \\
\hline DHW & $16.9 \mathrm{kWh} / \mathrm{m}^{2}$ & $19.6 \mathrm{kWh} / \mathrm{m}^{2}$ & $16.9 \mathrm{kWh} / \mathrm{m}^{2}$ \\
\hline Total & $40.2 \mathrm{kWh} / \mathrm{m}^{2}$ & $79.2 \mathrm{kWh} / \mathrm{m}^{2}$ & $143.5 \mathrm{kWh} / \mathrm{m}^{2}$ \\
\hline
\end{tabular}

\section{System simulation}

The systems' evaluation started with the definition of a reference system. An air-to-water heat pump (type 917) operates to provide space heating, space cooling and domestic hot water. For the space conditioning, the HP is coupled with a radiant floor panel system which works in both heating and cooling modes. To avoid the risk of condensation on the floor panels during the cooling operation, an air dehumidifier component (type 688) is modelled. The radiant floor panels are defined in the building model, as active layers within the floor. The water exiting the HP is provided with priority to the DHW tank when the temperature in the DHW tank goes below the set-point temperature $\left(50^{\circ} \mathrm{C}\right)$, or to the space-heating circuit, where the hot water flow is divided and controlled for each of the thermal zone. The temperature zone 


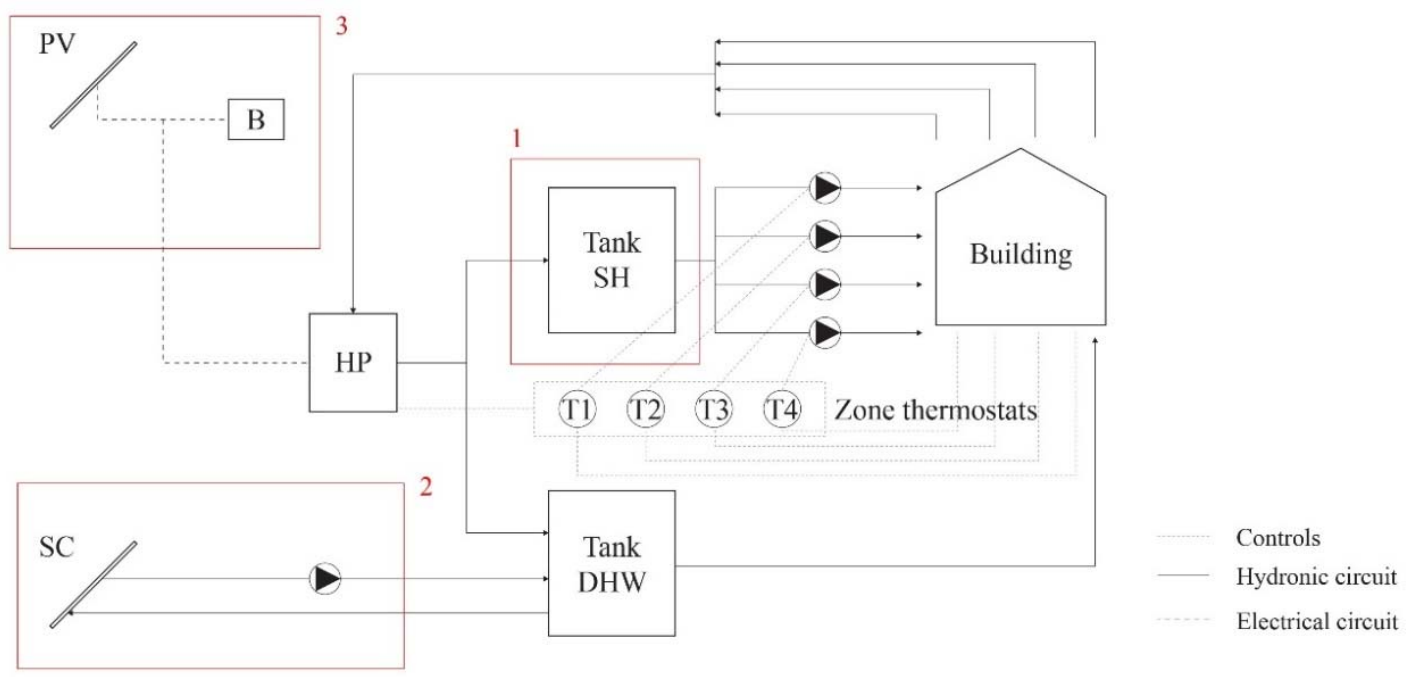

Figure 2: Schematic representation of the air-source heat pump system, with the three proposed implementations for the system

control is provided using four thermostats (type 108) using a temperature dead band of $1^{\circ} \mathrm{C}$ and the set-point temperature of $20^{\circ} \mathrm{C}$ for heating and $26^{\circ} \mathrm{C}$ for cooling.

Then, three different implementations for the heat pump system are proposed (Figure 2):

1. The integration of a buffer water tank within the hydronic distribution circuit;

2. The installation of solar collectors for the DHW production;

3. The installation of a photovoltaic plant and the integration of a battery storage system.

The optimization of these solutions is evaluated considering different component sizes and control strategies, as explained below. In the first case, the system is implemented by adding a water tank between the heat pump circuit and the radiant panel circuit of the building. The water tank is modelled with the type 60 in TRNSYS, as a stratified storage tank with 1501 volume. The loss coefficient of the buffer tank is assumed equal to 0.83 $\mathrm{W} / \mathrm{m}^{2} \mathrm{~K}$. The temperature is controlled by two aquastats for heating and cooling modes (type 2), using a proportional controller (type 1669), which controls the water temperature level considering the external temperature. The maximum and the minimum temperature allowed for the water tank are $35^{\circ} \mathrm{C}$ and 20 ${ }^{\circ} \mathrm{C}$ during the heating season. For the cooling season, the tank temperature varies from $26^{\circ} \mathrm{C}$ to $18{ }^{\circ} \mathrm{C}$. The effect of the tank temperature control is evaluated for two cases. In the first case, the temperature control is on when at least one of the building zone thermostats is on. In the second case, the temperature of the water tank is maintained at the set-point temperature for 12 hours, after the last control signal of the building zone thermostats.

Then, the integration of solar collectors is assessed for DHW preparation. The solar plant is composed by flatplate collector arrays (Type 1), installed with a slope of $45^{\circ}$. The impact of solar thermal collectors is investigated assuming the sizes of 1,5 and $10 \mathrm{~m}^{2}$ of panel installation. The collectors provide heat directly to the domestic water tank, until the tank reaches the temperature of $60^{\circ} \mathrm{C}$. In this case, the size of the DHW tank is increased to 3001 . The possibility of overheating the tank to $70^{\circ} \mathrm{C}$ is evaluated. In the end, a photovoltaic plant is integrated in the system, with a nominal power of around $1.20 \mathrm{kWp}$. The photovoltaic module is defined with type 94 in TRNSYS, as a polycrystalline module with an array slope of $45^{\circ}$. The electricity produced by the photovoltaic plant is directly delivered to the heat pump when required. The impact of the integration of an electric storage system is estimated. The electric storage (type 47) is a lead-acid battery with a cell energy capacity of $1.2 \mathrm{kWh}$ and a charging efficiency of 0.9 . The total capacity of the battery is defined by the number of cells, which varies from 1 to 16 . In a first case, the photovoltaic energy is sent with priority to the battery until it is charged, and then the electricity is sent to the grid or to the HP when required (charging mode CM1). In a second case, the electricity is sent to the battery only when the HP is not working (charging mode CM2). When the battery is totally charged, the electricity is sent to the grid. The optimization for the proposed solutions are summarised in Table 3.

Table 3: Building energy loads for each reference scenarios

\begin{tabular}{|c|c|c|c|}
\hline & $\begin{array}{c}\text { Minimum } \\
\text { value }\end{array}$ & $\begin{array}{c}\text { Maximum } \\
\text { value }\end{array}$ & $\begin{array}{c}\text { Variation } \\
\text { step }\end{array}$ \\
\hline SH tank control & $0 \mathrm{~h}$ & $12 \mathrm{~h}$ & 12 \\
\hline $\begin{array}{c}\text { DHW tank } \\
\text { temperature }\end{array}$ & $60{ }^{\circ} \mathrm{C}$ & $70{ }^{\circ} \mathrm{C}$ & 10 \\
\hline SC size & $1 \mathrm{~m}^{2}$ & $10 \mathrm{~m}^{2}$ & 5 \\
\hline Electric battery & $1.2 \mathrm{kWh}$ & $19.2 \mathrm{kWh}$ & 4.8 \\
\hline
\end{tabular}

\section{Economic analysis}

The economic analysis is carried out considering the Life Cycle Cost (LCC) of investment and energy costs of the 
systems. The LCC is calculated using the formula (1), considering a discount rate $r$ of 0.03 .

$$
L C C=\sum_{t=0}^{n} \frac{\text { Cost }}{(1+r)^{n}}
$$

Where $\mathrm{n}$ is the number of years of the reference period. In the study, the total cost is calculated for a reference period of 20 years. The energy cost is calculated considering an electricity price of $0.19 € / \mathrm{kWh}$. Then, the LCC is annualized to the starting year, using the following formula (2).

$$
\text { Annualized global cost }=\frac{L C C \times r}{1-(1+r)^{-n}}
$$

\section{Results}

The system simulations are run for the whole year, considering both heating and cooling seasons. For each insulation case, the reference system is simulated, considering a standard air-source heat pump. Then, the heat pump system is implemented with the integration of a buffer tank within the distribution circuit, the installation of solar collectors for the DHW production, and the installation of photovoltaic plant with a battery storage system. The results are expressed as primary energy consumption, using a conversion factor for the electricity of 1.95 .

For the high insulation case, the integration of the buffer tank leads to an increase of the energy consumption of about $50 \%$ (Figure 3). Due to the building's low energy demand, the water flow through the radiant panels is activated only for short periods of time and heating a larger quantity of water in the buffer tank is disadvantageous. The water collected in the tank is unused for large periods of time, and due to the thermal losses of the tank, the energy required to the heat pump for the whole system increases. Furthermore, changing the temperature control mode of the buffer tank, and maintaning the set-point temperature for 12 hours after the last thermostat signal from the thermal zones becomes more disadvantageous, bringing the increase of energy consumption to almost $65 \%$. The same consideration are also valid for the medium insulation case, where an increase of about $55 \%$ is found with both control modes.

Different results are found for the low insulation case. In this case, due to the high energy demand of the building, the heat pump works with higher temperatures and lower perfomance. The heat pump provides heat with priority to the DHW tank when required, and during this time the space heating is stopped and the temperatures in the thermal zones decrease. The integration of the buffer tank allows the space heating to work also when the DHW is required, maintaining the temperature in the thermal zones more stable. In this case, the energy consumption decreases by 5 to $7 \%$ for the two regulation modes.

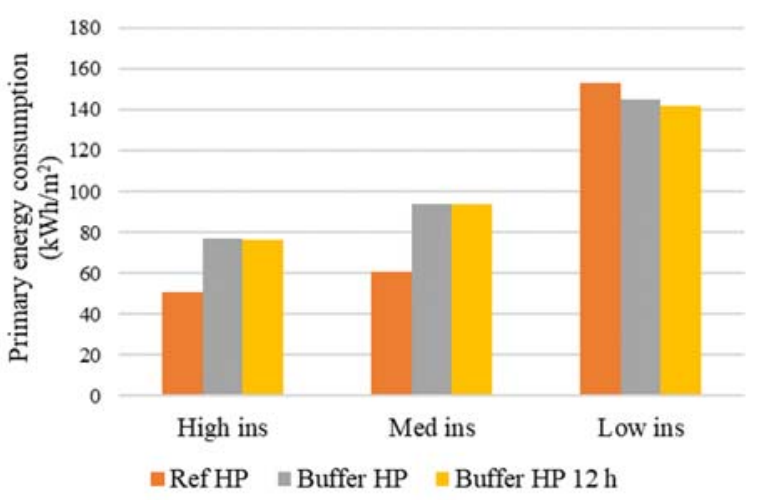

Figure 3 : Primary energy consumption for the three insulation cases, for the two reference systems (boiler and air-source HP, and for the heat pump system with the integration of a water tank within the distribution system

The integration of the solar panels is evaluated considering an installation area of 1,5 and $10 \mathrm{~m}^{2}$. Two different control strategies are applied, considering the maximum temperature for the DHW tank of $60{ }^{\circ} \mathrm{C}$ in the first case, and $70{ }^{\circ} \mathrm{C}$ in the second case. For the high insulation case (Figure 4) the total energy consumption are reduced up to $18 \%$ considering the maximum temperature of $60{ }^{\circ} \mathrm{C}$. By overheating the tank up to 70 ${ }^{\circ} \mathrm{C}$, the reduction of the consumption reaches $24 \%$.

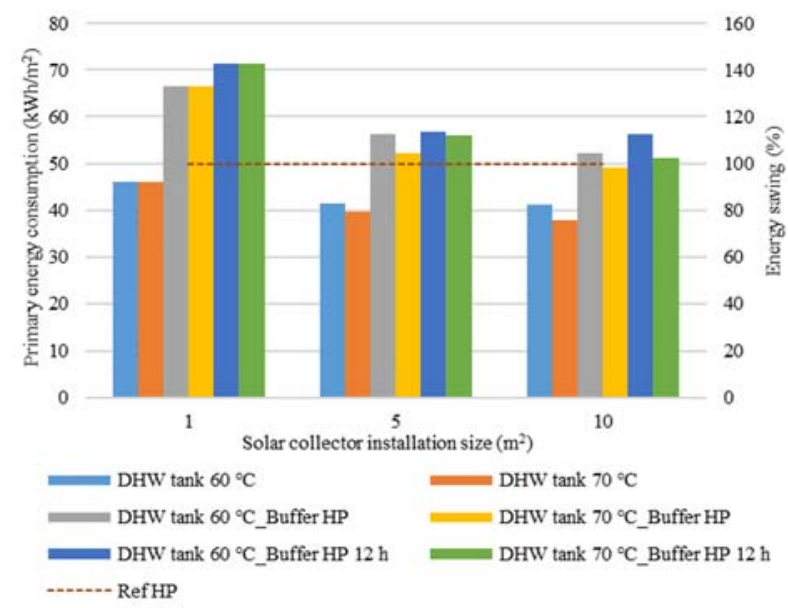

Figure 4: Primary energy consumption of the systems with the integration of thermal panels for the high insulation case, considering different installation sizes and the maximum DHW tank temperature of 60 and $70{ }^{\circ} \mathrm{C}$.

The integration of the thermal panels in the systems combined with the integration of the buffer tank in the space heating circuit brings the energy consumption to the level of the reference system with the heat pump only. For the medium insulation case (Figure 5), the total energy reduction reaches $10 \%$ with $60{ }^{\circ} \mathrm{C}$ and $15 \%$ with $70{ }^{\circ} \mathrm{C}$. Considering the low insulation case, the maximum energy reduction is $31 \%$ (Figure 6 ). 

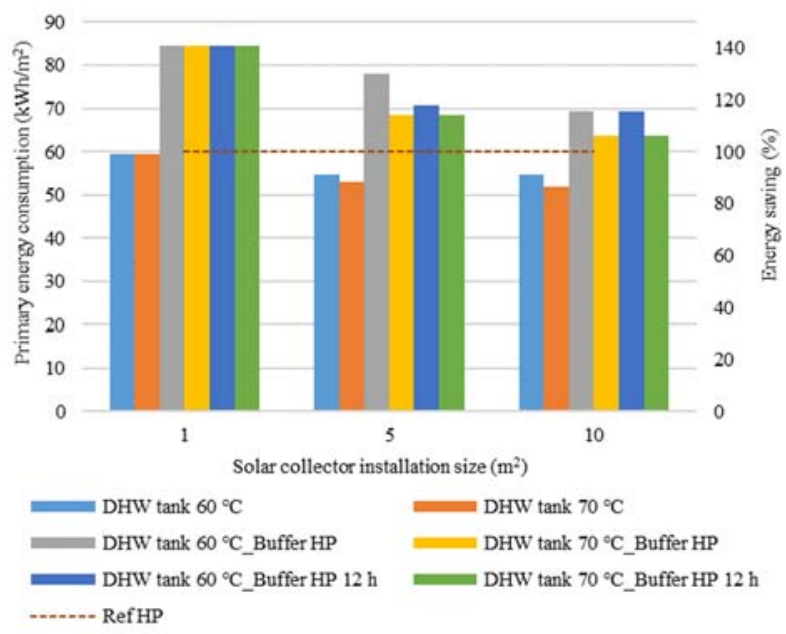

Figure 5: Primary energy consumption of the systems with the integration of thermal panels for the medium insulation case, considering different installation sizes and the maximum $\mathrm{DHW}$ tank temperature of 60 and $70{ }^{\circ} \mathrm{C}$.

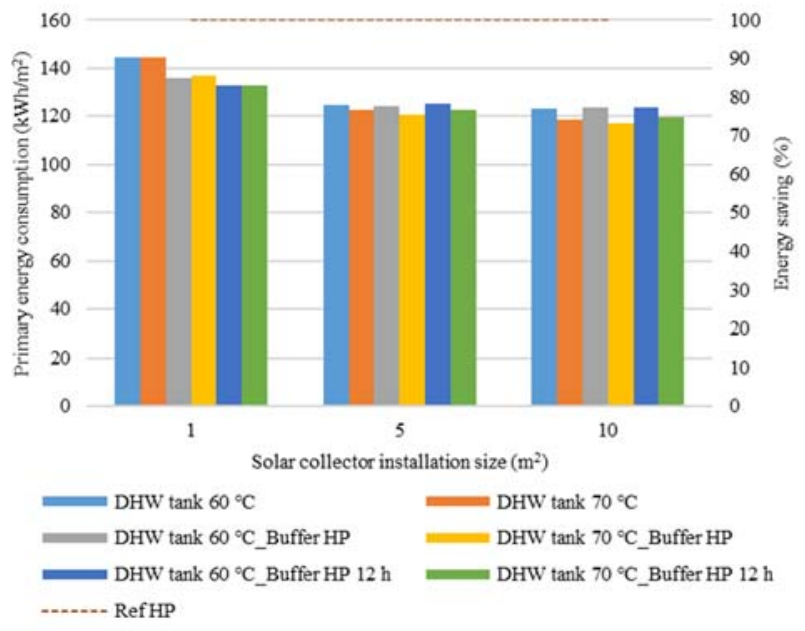

Figure 6: Primary energy consumption of the systems with the integration of thermal panels for the low insulation case, considering different installation sizes and the maximum DHW tank temperature of 60 and $70{ }^{\circ} \mathrm{C}$.

The installation of a $3.24 \mathrm{kWp}$ photovoltaic field is assessed for the three insulation cases. First, the photovoltaic plant is installed with no battery and then the integration of a storage system is evaluated. In the high insulation case (Figure 7), the maximum energy reduction reached is $27 \%$. The results show that increasing the battery capacity from 9.6 to $19.2 \mathrm{kWh}$ doesn't lead to any significant additional energy reduction. For the medium insulation case the reduction is $24 \%$ (Figure 8 ). Again, increasing the battery capacity from 9.6 to $19.2 \mathrm{kWh}$ doesn't affect the energy reduction significantly. For the low insulation case (Figure 9), the maximum reduction is $19 \%$, that is reached for the system with the water tank integration and the CM2 control strategy for the battery charge. In this case, the results show that the integration of the electric storage is not effective for the energy saving of the system, if compared with the installation of the photovoltaic plant without energy storage.

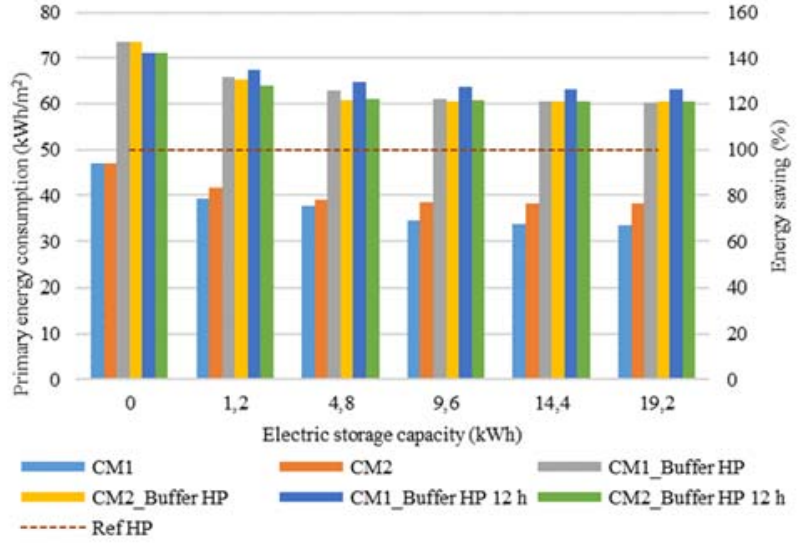

Figure 7: Primary energy consumption of the systems with the integration of $P V$ panels for the high insulation case, considering an electric storage capacity varying from 0 to 19.2

$k W h$. Two control strategies for the PV-battery system are investigated: CM1 if the energy from the PV is sent with priority to the battery until the total charge, CM2 is the PV energy is sent directly to the heat pump when required.

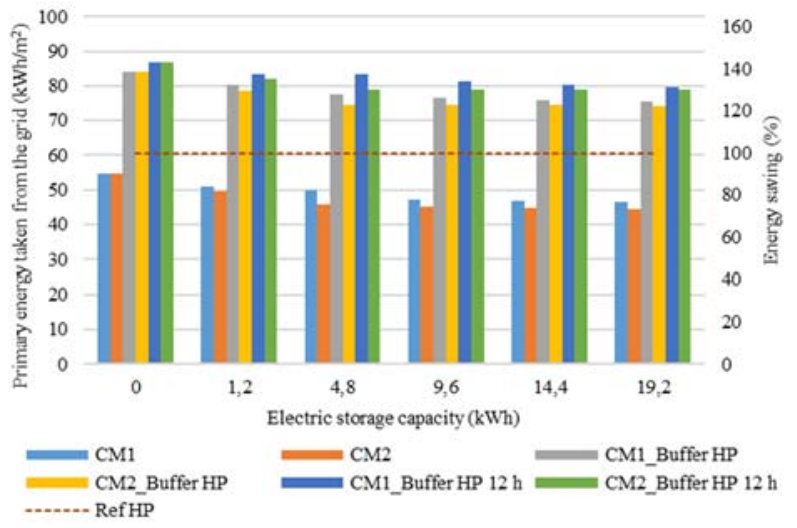

Figure 8: Primary energy consumption with the integration of $P V$ panels for the medium insulation case, considering an electric storage capacity varying from 0 to $19.2 \mathrm{kWh}$.

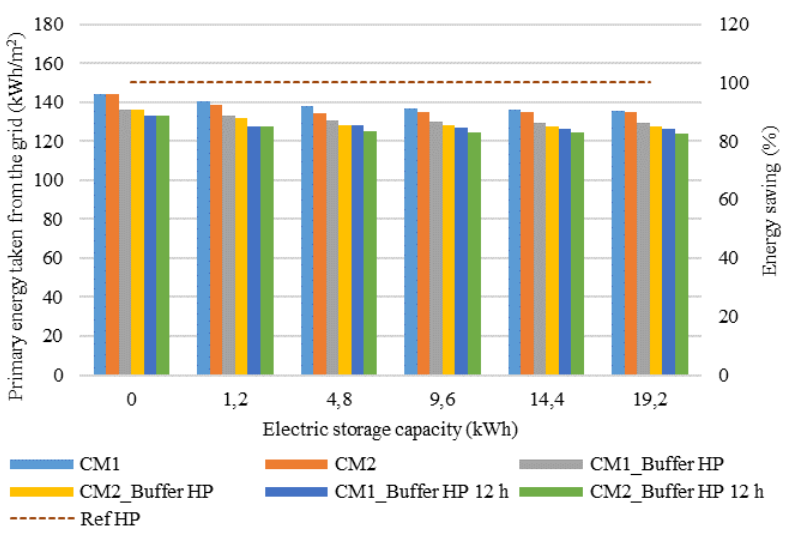

Figure 9: Primary energy consumption of the systems with the integration of $P V$ panels for the medium insulation case, considering an electric storage capacity varying from 0 to 19.2 $k W h$. 


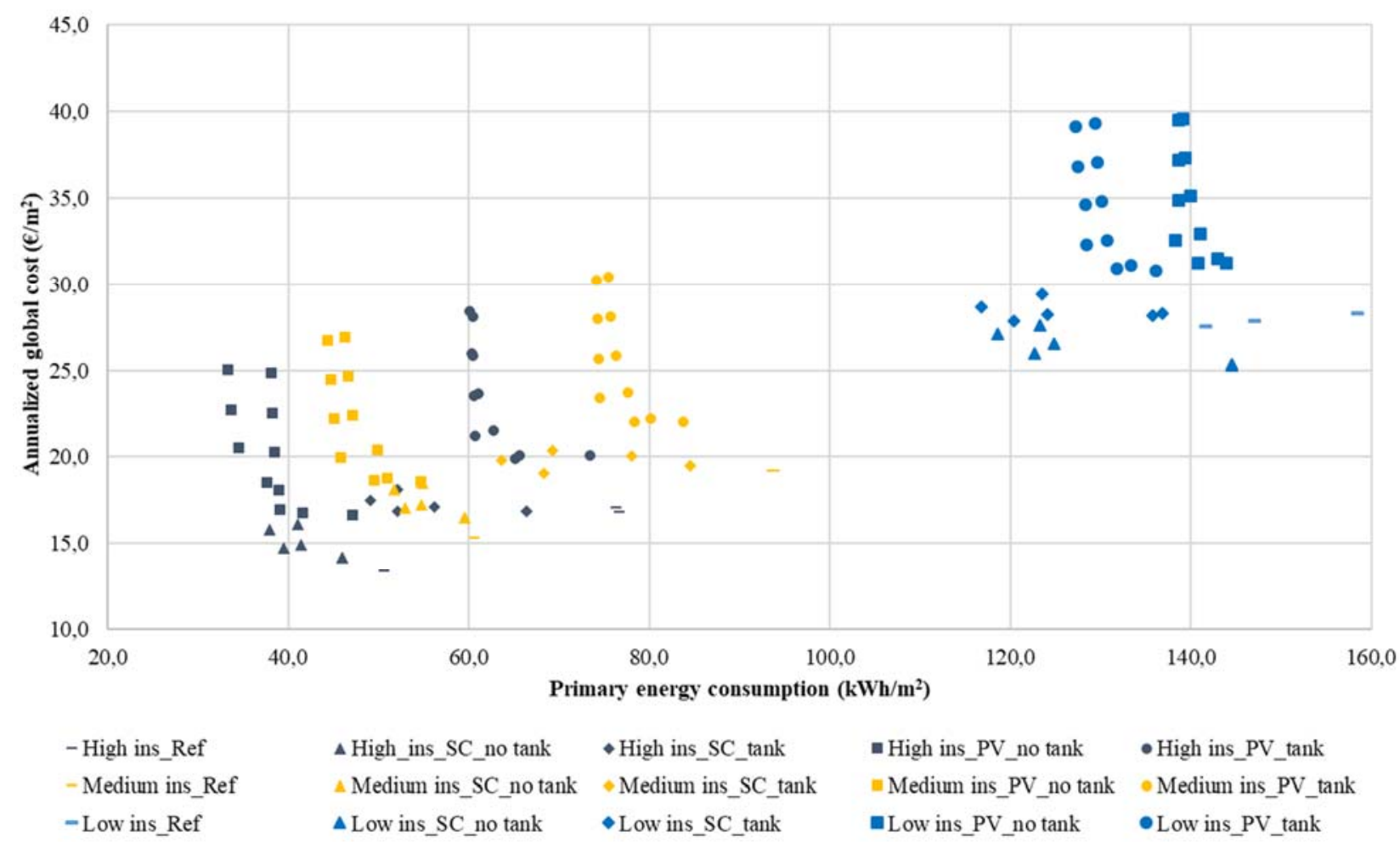

Figure 10: Annualized global cost and primary energy consumption rate per year for the proposed systems

An economic analysis was carried out for all the systems. The LCC for each system is calculated considering the investment cost and the energy cost for a reference period of 20 years. Then, the LCC is annualized to assess the annualized global cost. The relation between primary energy consumption and the global cost of each system is shown in the graph (Figure 10). The three colors show the results for the three insulation cases. The optimal solutions are characterised by lower energy consumption and lower cost, and they can be identified in the graph as

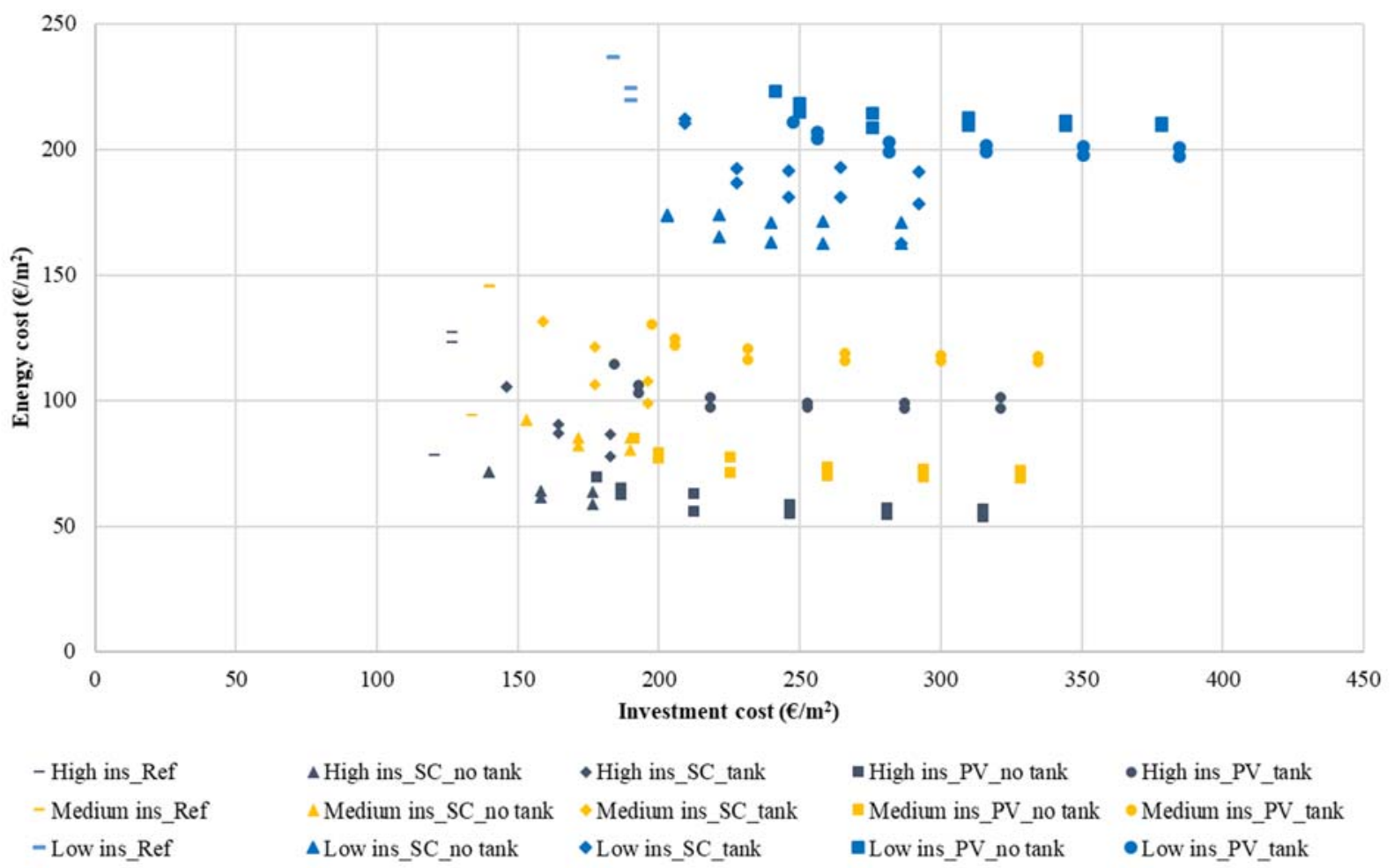

Figure 11: Unitary energy cost and investment cost for the proposed systems 
the points on the lower left part for each case. In particular, the installation of the photovoltaic plant for the high and medium insulation cases, are the most expensive but, at the same time, the most efficient systems. For the high insulation case (grey colour) the SC installation turns out to be the optimal solution, while for the medium insulation case the $\mathrm{PV}$ becomes competitive in comparison to the SC. For the low insulation case, the PV installations are again the most expensive solutions, but not the most efficient. In this case, the integration of thermal panels results more efficient for the energy reduction of the system.

Considering the different implementation strategies, it is noticeable that the increase of the size components after a certain level leads to a high increase of annualized global cost with a slight decrease of the energy consumption. This aspect is shown in the graph (Figure 11) showing the relation between investment cost and energy cost. In this case, the systems with higher investment costs are characterised by lower energy costs. The reduction of the energy cost leads to pay back the higher investment costs over the year, making the most efficienct systems more profitable from an economic point of view.

\section{Conclusions}

This paper shows the energy consumption of different systems applied to a residential building in Bozen, in northern Italy. The building is modelled with three different insulation cases. Starting from a reference system, designed with an air-source heat pump, other systems are defined integrating a buffer tank within the distribution system, the installation of solar thermal panels and photovoltaic panels, with and without electric storage system.

The effectiveness of the energy storage integration has been evaluated for the three cases:

- The use of a buffer tank results profitable for the low insulation case, but not for the high and medium insulation cases. This is because the buildings with lower energy demand have a small space heating energy use, and the energy stored in the buffer tank is greatly affected by thermal losses. For the low insulation case, the number of charging and discharging cycles is greater, and the use of the buffer tank is effective to maintain the zones' temperatures more constant when the DHW is also required.

- The integration of the battery within the PV installation is effective for the high and medium insulation case. Moreover, increasing the storage capacity over the $9.6 \mathrm{kWh}$ doesn't increase significantly the energy saving of the systems. For the low insulation case, doesn't impact significantly the results if compared to the PV installation without energy storage.

In the end, specific considerations can be made for the three insulation cases:

- For the high insulation case, the integration of $\mathrm{PV}$ and SC panels lead to similar results in term of energy reduction ( $27 \%$ and $24 \%$ respectively). However, the PV integration results less profitable considering the annualized global cost, if compared with the SC.

- For the medium insulation case, the integration of $\mathrm{SC}$ is less effective in term of energy reduction (15\%), if compared with the PV panels integration $(24 \%)$. In this case, the higher investment cost for the PV system can be profitable over the reference period, due to the lower energy cost.

- For the low insulation case, the integration of PV panels becomes less effective, with a maximum reduction of $19 \%$, while the SC installation can lead to an energy reduction of around $30 \%$.

\section{Nomenclature}

$\begin{array}{ll}\text { CM } & \text { Charging Mode } \\ \text { DHW } & \text { Domestic Hot Water } \\ \text { HP } & \text { Heat Pump } \\ \text { LCC } & \text { Life Cycle Cost } \\ \text { NZEB } & \text { Net Zero Energy Building } \\ \text { PV } & \text { Photovoltaic } \\ \text { SAHP } & \text { Solar Assisted Heat Pump } \\ \text { SC } & \text { Solar Collector }\end{array}$

\section{References}

Al-alili, A., Y. Hwang, and R. Radermacher (2013). Review of Solar Thermal Air Conditioning Technologies. International Journal of Refrigeration 39, 4-22.

Antoniadis, C.N., and G. Martinopoulos (2017). Simulation of Solar Thermal Systems with Seasonal Storage Operation for Residential Scale Applications. Procedia Environmental Sciences 38, 405-12.

Battaglia, M., R. Haberl, E. Bamberger, and M. Haller (2017). Increased Self-Consumption and Grid Flexibility of PV and Heat Pump Systems with Thermal and Electrical Storage. Energy Procedia 135, 358-66.

Bee, E., A. Prada, and P. Baggio (2016). Optimization of Air-Source Heat Pump Systems over the Heating Season through the Use of Renewable Energy Sources. International Compressor Engineering, Refrigeration and Air Conditioning, and High Performance Buildings Conferences, 1-9.

Bellos, E., and C. Tzivanidis (2017). Energetic and Financial Sustainability of Solar Assisted Heat Pump Heating Systems in Europe. Sustainable Cities and Society 33, 70-84.

Buker, M. S., and S. B. Riffat. (2016). Solar Assisted Heat Pump Systems for Low Temperature Water Heating Applications: A Systematic Review. Renewable and Sustainable Energy Reviews 55, 399-413.

European Committee for Standardization-CEN (2016). 
EN12381. Energy Performance of Buildings Method for Calculation of Design Heat Load - Part 3: Domestic Hot Water Systems Heat Load and Characterisation of Needs, Module M8-2, M8-3."

European Parliament (2009). "Directive 2009/28/EC of the European Parliament and of the Council of 23 April 2009 on the Promotion of the Use of Energy from Renewable Sources and Amending and Subsequantly Repealing Directives 2001/77/EC and 2003/30/EC." Official Journal of the European Union 140 (16), 16-62.

European Parliament (2010). Directive 2010/31/EU of the European Parliament and of the Council of 19 May 2010 on the Energy Performance of Buildings (Recast), 13-35.

Facci, A., V. Krastev, G. Falcucci, and S. Ubertini (2018). Smart Integration of Photovoltaic Production, Heat Pump and Thermal Energy Storage in Residential Applications. Solar Energy.

Fischer, D., K. B. Lindberg, H. Madani, and C. Wittwer (2017). Impact of PV and Variable Prices on Optimal System Sizing for Heat Pumps and Thermal Storage. Energy and Buildings 152, 843.

Haller, M. Y., J Paavilainen, L. Konersmann, R. Haberl, A. Dröscher, C. Bales, W. Streicher, et al. (2010). A Unified Model for the Simulation of Oil, Gas and Biomass Space Heating Boilers for Energy Estimating Purposes . Part I : Model Development. Journal of Building Performance Simulation 4, 118.

Haller, M., E. Bertram, R. Dott, T. Afjei, F. Ochs, C.
Sunliang, K. Siren, and J.-C. Hadorn (2013). Models of Sub-Components and Validation for the IEA SHC Task 44 / HPP Annex 38 Part A: Summary."

Hardorn, J.-C., ed. (2015). Solar and Heat Pump Systems for Residential Buildings.

Henning, H.-M. (2007). Solar Assisted Air Conditioning of Buildings: an Overview. Applied Thermal Engineering 27, 1734-49.

Ibrahim, H., A. Ilinca, and J. Perron (2008). Energy Storage Systems: Characteristics and Comparisons. Renewable and Sustainable Energy Reviews 12, 1221-50.

Januševičius, K., and E. Biekšienè (2013). Parametric Study of the Solar Assisted Heat Pump Performance. Cyseni 10,: 1-10.

Lerch, W., A. Heinz, and R. Heimrath (2014). Evaluation of Combined Solar Thermal Heat Pump Systems Using Dynamic System Simulations. Energy Procedia 48, 598-607.

Moser, D., C. Breyer, G. Masson, and E. Vartiainen (2017). Improving the Competitiveness of Solar PV with Electricity Storage. In 33rd European Photovoltaic Solar Energy Conference and Exhibition, 2783-89.

Tzivanidis, C., E. Bellos, G. Mitsopoulos, K. Antonopoulos, and A. Delis (2016). Energetic and Financial Evaluation of a Solar Assisted Heat Pump Heating System with Other Usual Heating Systems in Athens Coefficient of Performance. Applied Thermal Engineering 106, 87-97. 